Kaz DZIAMKA

Central New Mexico Community College, USA

\title{
Want to teach secular humanism?: Here's a course proposal you could use
}

\begin{abstract}
Tt was in 1995: for some reason my topics course proposal to teach secular humanism had been approved by the Albuquerque TVI, a community college in New Mexico, and I taught it in the fall of that year as a General Honors course. For 15 minutes I became famous, making the front page of the "Albuquerque Journal". Annie Laurie Gaylor, editor of "Freethought Today", wrote that mine was "undoubtedly, the first course in secular humanism [ever taught] at a technical vocational institute [in the US]." Not clear, though, whether such trivia is cause for joy or profound sadness.
\end{abstract}

A story of secular humanism is a sad story, just as a song of love is a sad song. In May 1996 - on my birthday, as it happened - I got a letter terminating my contract at TVI. No reason given. Clearly, not incompetence, if only because at the time of my dismissal, I was offered a prestigious, competitive Fulbright grant to teach American literature at the University of Tromsř in Norway, the first TVI instructor to have received such an academic honor. Also, by that time I had written and published a college textbook to teach English grammar, Sentences: An Introduction to Syntax. (Another "first": no other TVI Arts and Sciences instructor had before published a college textbook. Mine was used for three years to teach Traditional English Grammar at TVI.) And of course, I have academic degrees: an MA in English Philology (from the Jagiellonian University, Cracow, Poland) and a PhD in American Studies (from the University of New Mexico).

But I am a secular humanist ... and I had taught a course in secular humanism in God's chosen country: the Christian States of Corporate-Military America. So I would have to be taught a lesson. And I was. No public American college or university would ever touch me again. I was blacklisted: As a Fulbright scholar I sent out over 50 applications to colleges and universities throughout the country only to find that not only would I never get an interview, I would not even be dignified with 
a "no-thank-you" note. My academic career was effectively destroyed. I might still hope to teach at a third-rate college - on an Indian res perhaps (not a bad prospect, actually, except that many Native Americans, having become deluded Christians, would not have anything to do with me either.)

Such is the unrelenting vengeance of the American academic-political establishment. With a few exceptions, admittedly but insignificantly, the purpose of education in America is not to offer unfettered knowledge and academic freedom - but to enforce blind conformity to the existing corporate establishment and to Christian and other politically convenient myths and superstitions: "America is a City upon a Hill" (no, it's not); "the greatest democracy in the world" (no, it's not: never has been, is not, and most likely never will be); "promotes peace and democracy" (no, it does not); "best country to live in" (no, it's not).

And so I had to fight somehow to survive: I and my family. I joined a class-action suit against TVI for an unlawful termination of my job. Faced with a potentially tough and embarrassing battle in court (I got a lot of support from my colleagues and students), the then TVI administration chose to offer me reinstatement. I accepted and decided to survive, rather than to succeed. No longer, not ever again, would I teach secular humanism.

But, to paraphrase a Master, humanist hopes spring eternal in the human heart. This is 2006, eleven years after those sad, unpleasant events. I no longer teach at TVI. Now I teach at CNM, same school, but a different name and image and a higher level of professionalism. I have a new boss, a dean whom until recently I could only imagine in my incorrigible expectations. The previous dean is gone from my department at last. (For much longer she has also been gone from my life, even though she remained the dean of the department I was in for nearly seven years after I was reinstated and made my life a living hell. But I have learned a certain psychological maneuver to shut her out - and others like her - for ever from my life. And so for all I know, she doesn't exist any more. And hasn't for 11 years.

I cannot live in the future all the time. There are now no tomorrows in my life. I plan every day as if tomorrow never comes. I am learning to live in the here and now. "Here and now, boys," as the mynah birds sing in Huxley's sad ecotopia, Island. "Attention, here and now, boys." And girls, of course.

So here and now I go again: I just re-submitted my humanism course proposal. I have modified it somewhat, but it's not much different from the 
1995 original. I do not necessarily expect to have this proposal acceptedgreat new dean or not (the actual decision is up to the curriculum committee) - but it is better to submit a humanism course proposal than not to submit it at all - just as it is better to try to love than not to try at all.

If you are a bona fide scholar of humanism, please take advantage of my tested, proven proposal. It is my intellectual property, and that of the American Rationalist, but you may customize it and use it as your own. It follows all the strict academic guidelines for topics course submissions any respectable school or college might require.

We need to start teaching secular humanism in high schools and colleges all over the world. Now more than ever.

I wish you well. Take care!

\section{A GENERAL HONORS TOPICS COURSE PROPOSAL}

Submitted by Kaz Dziamka, PhD

Central New Mexico Community College: Communication, Humanities and Social Sciences Division

\section{"The American Humanist Tradition"}

General Honors 211, 3 credit hours

(Prerequisite: 9 hours of arts and sciences courses, 3.2 or higher cumulative GPA, a $B$ or better in English 101)

\section{DESCRIPTION:}

The course offers a rare opportunity to study American Humanists and Humanism - a secular lifestyle and a "rational philosophy informed by science, inspired by art, and motivated by compassion."

\section{OBJECTIVES:}

\section{Students will}

1. study the goals and principles of a secular, scientific, non-religious philosophy of life known as Humanism as promoted by the

United States leading Humanist organizations: The American Humanist Association (AHA) and the Council for Secular

Humanism (CSH) 
2. trace the origins of Humanism in Western, particularly Greek and Roman, philosophy

3. read the most prominent American and a few other Humanists: political leader and famous agnostic Robert Ingersoll;

philosophers Corliss Lamont and Paul Kurtz (Chairman and Founder of $\mathrm{CSH}$ and Editor in Chief of Free Inquiry); Fred

Edwords (Editor of the Humanist); feminists Barbara Ehrenreich (1998 Humanist of the Year) and Annie Laurie Gaylor (Editor

of Freethought Today); birth control activist Margaret Sanger; British Humanist activists Margaret Knight and Barbara Smoker

(President of the National Secular Society); astronomer and writer Carl Sagan; novelists Kurt Vonnegut (Honorary President of

AHA) and Gore Vidal; "Star Trek" creator Gene Roddenberry.

4. discuss what Humanists argue are enormous "hidden costs" of religious belief, often resulting in - among others - "psychic

surrender," bigotry, intolerance, religious hatred, and holy wars

5. debate the secular aspect of American democracy, particularly the current First Amendment problems and dilemmas.

\section{MEANS OF ASSESSMENT:}

A class presentation, several quizzes, a midterm essay, an MLA research paper

\section{JUSTIFICATION:}

"The American Humanist Tradition" will complement the standard Honors and Humanities courses offered by CNM: "The Ancient Legacy" (121A), "The Modern Legacy" (121M), Early World Civilization (HUM 111), and Modern World Civilization (HUM 121). Among ancient Greeks, Protagoras is sometimes called "the first humanist." Humanist themes are found in Lao Tzu, Confucius, Epicurus,Lucretius, Seneca, Epictetus, Celsus. The humanist tradition continues in the writings of Montaigne, Spinoza, Voltaire, Baron D'Holbach, Thomas Paine, Charles Darwin, Sigmund Freud, Bertrand Russell, Margaret Knight, Jacob Bronowski-to name just a few representative thinkers.

The course is directed to Honors students, but it should also appeal to those who study religion, political science, philosophy, literature, cultural studies, and American studies. Of course, anybody interested in a secular lifestyle should consider taking "The American Humanist Tradition." 
Although this course shares some topics with Honors and Humanities courses, it nevertheless offers a distinct, unique, multi-disciplinary reinterpretation of these topics from a Humanist, secular perspective.

The course was unique when it was offered for the first time at a technical-vocational college in 1995 - at TVI. The course remains so today. To my knowledge, CNM is the only community college in the country to have offered an Honors course in American Humanism. As Annie Laurie Gaylor, editor of Freethought Today (published in Wisconsin), points out, the course I have taught is "Undoubtedly, the first course in secular humanism taught at a technical vocational institute."

"The American Humanist Tradition" should be taught again at CNM if only because it generated a high level of interest among TVI (and UNM) students in 1995, attracting local and national media attention. The enrollment capped out at 18.

\section{ADDITIONAL COURSE INFORMATION:}

No additional resources are required to teach "The American Humanist Tradition," although I do intend to invite guest speakers from the local chapter of the American Humanist Association and from the Center for Inquiry in upstate New York. No special scheduling is required. The course may be offered either once or twice a week. As mentioned above, the course was offered at TVI in the fall of 1995. Fliers will be posted on CNM campuses and distributed among faculty. I will ask the Albuquerque Journal and Alibi, both of which ran front-page stories of my course in 1995, to publish an ad about the course.

\section{OTHER}

Here is a sample reading list: (The actual list is much longer and includes editorials and essays currently published in Humanist journals: The Humanist, Free Inquiry, Freethought Today, and The American Rationalist.)

1. Corliss Lamont, The Philosophy of Humanism

2. Paul Kurtz, The Transcendental Temptation, Science and Religion (ed.)

3. Carl Sagan, The Demon-Haunted World

4. Margaret Knight, Humanist Anthology

5. J. Blau, "The Origin of Secular Humanism in the American Tradition"

6. Fred Edwords, "Life Is to Be Lived Now"

7. Annie Laurie Gaylor, Woe to the Women - The Bible Tells Me So

8. R. Buchsbaum, "Is There a Better Pledge of Allegiance?" 
9. James Haught, Years of Disbelief, Holy Hatred

10. Paul Blanshard, ed., Classics of Free Thought

\section{PROPOSER INFORMATION:}

\section{Kaz Dziamka}

PhD (American Studies, UNM)

MA (English Philology, Jagiellonian University, Cracow, Poland)

At TVI/CNM, I have taught courses in English, Cultural Studies, Native American Studies, and General Honors. My special qualifications include the following:

- I have been Editor-in-Chief of the American Rationalist for 10 years. (AR, a humanist-rationalist journal, has been published continually since 1953.)

- I am a lifetime member of the American Humanist Association and of the Council for Secular Humanism, a leading Humanist organization in the world.

- I have been a featured speaker on Humanism at several national and international conferences (Norway and Poland).

- I gave a presentation on Humanism to Fulbright scholars and students in Norway in 1999. (I taught American literature on a Fulbright grant at the University of Tromsø in 1998/1999.)

\section{Summary}

Autor artykułu z emocjonalnym zaangażowaniem opisuje koleje swojej kariery w Albuquerque Technical Vocational Institute w Nowym Meksyku, niespodziewanie przerwanej otrzymaniem wypowiedzenia, którego przyczyny upatruje w reprezentowanym światopoglądzie, znajdującym wyraz w nauczanym przezeń kursie przedstawiającym świecką tradycję humanizmu. Dając wyraz swojemu bardzo krytycznemu stosunkowi do atmosfery intelektualnej panującej w USA, które nie są jego zdaniem państwem demokracji, swobody ani pokoju prezentuje program kursu, który ponownie prowadzi po wygraniu prawnej batalii o bezprawne zwolnienie. 